(C)2006 IEEE. Personal use of this material is permitted. However, permission to reprint/republish this material for advertising or promotional purposes or for creating new collective works for resale or redistribution to servers or lists, or to reuse any copyrighted component of this work in other works must be obtained from the IEEE. 


\section{A Current-Sensor-Free Incremental Conductance Single Cell MPPT for High Performance Vehicle Solar Arrays}

\author{
Peter Wolfs \\ Central Queensland University \\ Rockhampton Mail Center, QLD 4702, Australia \\ Email: p.wolfs@cqu.edu.au
}

\author{
Quan Li \\ Central Queensland University \\ Rockhampton Mail Center, QLD 4702, Australia \\ Email: q.li@cqu.edu.au
}

\begin{abstract}
A Maximum Power Point Tracker has been previously developed for a single high performance GaAs solar cell for hybrid and electric vehicle applications. This paper presents a new Maximum Power Point Tracking (MPPT) control algorithm which is based on the Incremental Conductance (IncCond) method but does not require any current sensing devices. In this new algorithm, the condition for the Maximum Power Point (MPP) operation can be established from the solar cell voltage and the converter switching duty ratio alone. The method can also be readily applied to any load type where power increases monotonically with voltage. A solar cell model for the triple junction cell is also thoroughly discussed. This model is used in the simulation circuit and the results for the new MPPT method are provided. Finally, a solar cell simulator and a $600-\mathrm{mW}$ buck converter switching at $20 \mathrm{kHz}$ controlled by Texas Instrument MSP430 microprocessor are used as the test platform for the new IncCond MPPT algorithm. The experimental results show that the proposed MPPT algorithm has secured a $1.5-\mathrm{ms}$ response time due to insolation changes.
\end{abstract}

\section{INTRODUCTION}

The automotive industry has recently seen increasing markets for hybrid and electric vehicles, which can gain a useful energy input and range extension by the inclusion of high performance solar arrays [1], [2]. As the areas are limited, curved for aerodynamic reasons and subject to rapid insolation changes due to shadowing by roadside objects, highly efficient solar cells and highly distributed MPPT schemes are desired.

Photovoltaic cells with high efficiencies such as monocrystalline GaAs dual and triple junction cells can be applied in this application. Both Emcore and Spectrolab manufacture triple junction cells and Fig. 1 shows a triple junction cell from Emcore [3].

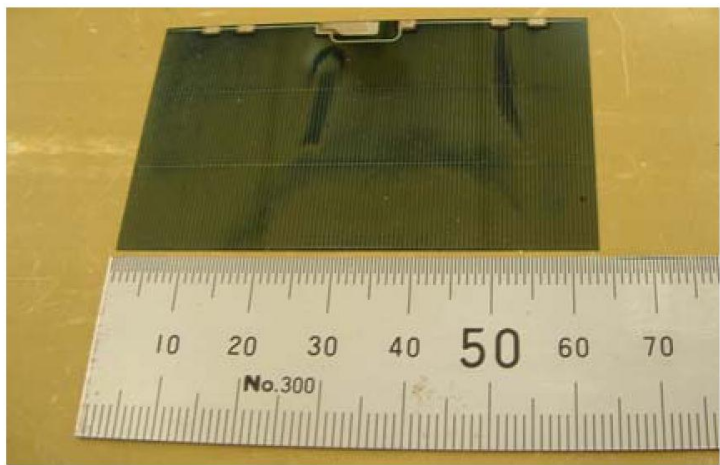

Fig. 1. Emcore triple junction cell
For high performance vehicle solar arrays, distributed maximum power tracking devices targeting at a small number of cells are preferred as vehicle arrays have curvature and shadowing by roadside objects produces very rapid insolation changes. However, challenges do exist such as the cost, the size and the efficiency of the MPPT devices.

This paper presents a new MPPT method based on the IncCond method. The new MPPT method is able to establish the MPP purely against the solar cell output voltage and the converter switching duty ratio. The cell voltage can be easily obtained by a microprocessor equipped with an integrated Analogue-to-Digital Converter (ADC). In addition, the Maximum Power Point Tracker employs the buck converter design and therefore does not require any inductors at the converter level. A group of converters can share a single inductor [4]. The reduction in component count makes the MPPT application possible for small numbers of cells and potentially at the single cell level. A well-established triple junction solar cell model is provided and used in the simulation for the new MPPT algorithm. Finally, both simulation and experimental results are provided at the end of the paper. The experimental results confirm that under instantaneous insolation changes, a 1.5$\mathrm{ms}$ response time has been secured in the establishment of the new MPP.

\section{Buck Converter Design}

A laboratory prototype dc-dc converter with the MPPT controller has been previously developed and is shown in Fig. 2.

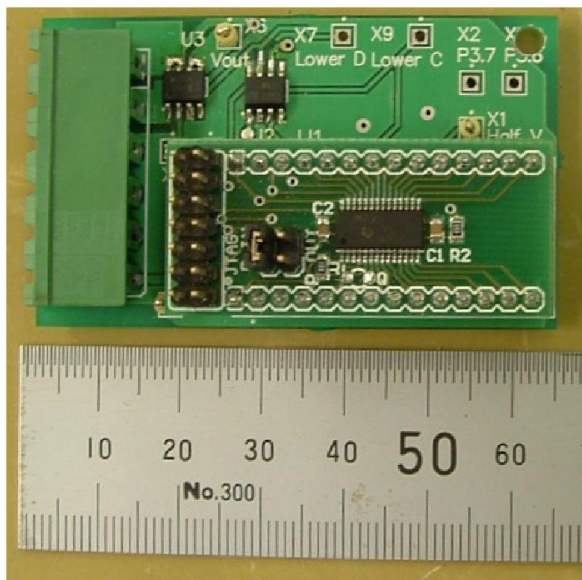

Fig. 2. Prototype dc-dc converter 
The buck converter topology is selected as this allows the inductor to be shared on the load side by multiple MPPT devices. The Texas Instrument MSP430 microprocessor is selected as the controller due to its low power consumption design. Additionally, the selected microprocessor is designed for $1.8-\mathrm{V}$ supply voltage and this opens the opportunity for it to be directly powered from a single solar cell.

Fig. 3 shows the circuit diagram of the buck converter. As the single cell output voltage is low, a charge pump circuit made up of four Schottky diodes and four capacitors is used to obtain a higher voltage to supply the gate drive circuit. From top to bottom, Fig. 4 respectively shows the waveforms of the two MOSFET gate voltages and the output mid-point to ground voltage in the buck converter. Calorimetry measurements [5] have confirmed that the 600$\mathrm{mW}$ converter achieves $93 \%$ efficiency switching at $20 \mathrm{kHz}$ [4].

\section{MPPT CONTROL AlgORITHMs}

Among a variety of existing online MPPT control algorithms, perhaps the simplest method is the one based on

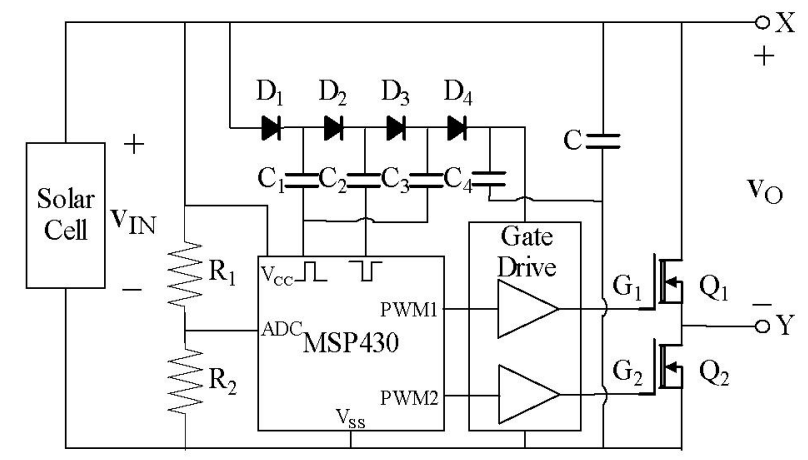

Fig. 3. Buck converter circuit diagram

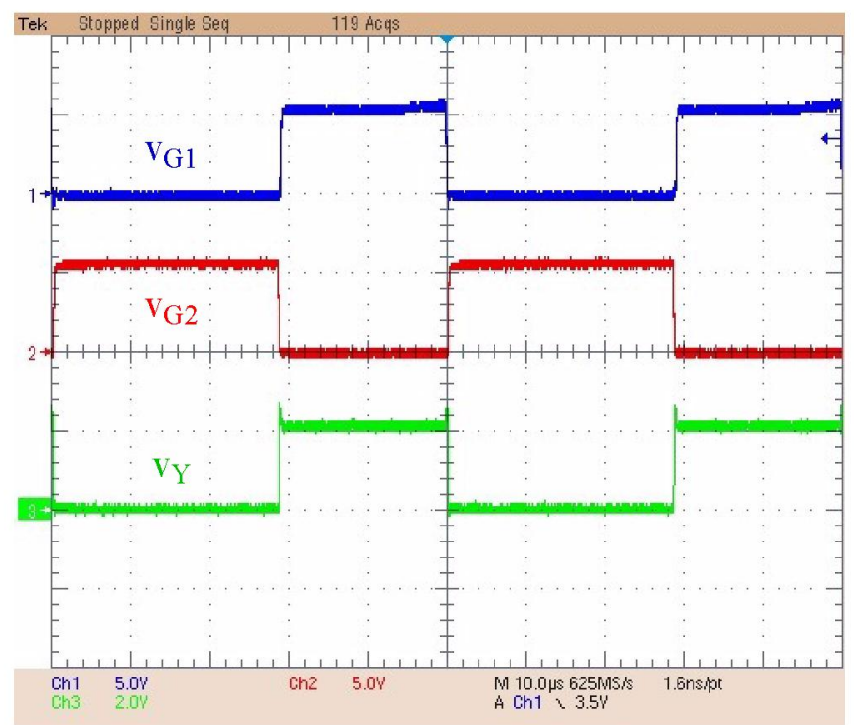

Fig. 4. Buck converter switching waveforms measuring the cell short circuit current [6], [7] or open circuit voltage [8]-[10]. These methods measure the short circuit current or the open circuit voltage of the solar cell at the beginning of each sampling period and then force the cell output current to be $92 \%$ of the short circuit current or the cell output voltage to be $76 \%$ of the open circuit voltage to maximize the cell output power. Although these approaches are extremely easy to implement, they are not very accurate as the percentages of the cell current or voltage at the MPP to the short circuit current or open circuit voltage have slight variations over the range of the insolation levels and the cell temperatures. Also, the power loss over the measuring interval may be significant and this is normally not cost-effective.

Two popular online MPPT control algorithms are Hill Climbing or Perturb and Observe (P\&O) and IncCond methods [11]. In P\&O method, the cell voltage is perturbed every MPPT cycle and the cell output power is calculated [12]. The direction of the cell voltage perturbation in the following MPPT cycle will be given by the sign of the power change. One inherent drawback in this method is the oscillation around the MPP since the cell voltage needs to be constantly perturbed. The operating point can also greatly depart from the MPP under rapidly uni-directionally changing atmospheric conditions as the power increase or decrease due to the increase or decrease of the insolation level can be mistakenly taken as a result of the cell voltage perturbation. A more sophisticated and accurate method is IncCond [13]. At the beginning of each MPPT cycle, the cell voltage moves with a constant step toward the direction determined by the comparison of the cell instantaneous and incremental conductances. After the MPP is reached, this comparison will be bypassed and the cell voltage oscillation can be avoided.

Both $\mathrm{P} \& \mathrm{O}$ and IncCond methods require the cell current measurement for power or conductance calculation. This normally contributes to a significant portion of the cost in an MPPT with a power rating in the milliwatt range. If $\mathrm{p}$ and $\mathrm{v}$ are respectively the instantaneous output power and voltage of the solar cell, the condition of the MPP is:

$$
\frac{d p}{d v}=0
$$

In the application where tens up to hundreds of the converters are series connected for the solar array on the vehicles, the load can be assumed as the constant current load since the voltage change of one single cell only causes minor change in the load current. In this case, the output voltage of the individual converter is proportional to its output power. Therefore, the load power can be solely represented by the converter output voltage. More generally, this approach is valid for all load characteristics with the output voltage being a monotonically increasing function of the output power. If the load power is to be maximized and $\mathrm{V}_{\mathrm{L}}$ is the load voltage, (1) can be rewritten as: 


$$
\frac{d v_{L}}{d v}=0
$$

The cell voltage is ground referred and readily measurable. If $\mathrm{D}$ is the switching duty ratio of the buck converter, the transfer function of the converter is:

$$
v_{L}=D v
$$

Substitution of (3) to (2) yields:

$$
D+v \frac{d D}{d v}=0
$$

According to (4), the operating point is to the left of the MPP when $D+v d D / d v>0$, to the right of the MPP when $D+v d D / d v<0$ and at the MPP when $D+v d D / d v=0$. The detailed operation of the proposed MPPT algorithm within $\mathrm{k}^{\text {th }}$ MPPT cycle is given in Fig. 5, where $V_{\text {ref }}$ is the desired cell voltage, $\mathrm{C}_{V}$ is the step length of the desired cell voltage in one MPPT cycle and threshold $\varepsilon_{\mathrm{j}}(j=1,2,3)$ is a small positive number close to zero. The magnitudes of the thresholds in the flowchart are determined by the step length and gains in the Proportional-Integral (PI) controller. In order for the algorithm to work properly, it is required that $\varepsilon_{1}<C_{V}$ and the other two thresholds can be obtained through trial and error.

\section{Triple Junction Solar Cell Model}

The Spectrolab $\mathrm{GaInP}_{2} / \mathrm{GaAs} / \mathrm{Ge}$ triple junction cell is used in the simulation. The output voltage and current of the solar cells are governed by the following equations [12]:

$$
\begin{gathered}
i=I_{g}-I_{\text {sat }}\left\{\exp \left[\frac{q}{A K T}\left(v+i R_{s}\right)\right]-1\right\} \\
I_{g}=\left[I_{s c}+K_{I}\left(T-T_{r}\right)\right] \frac{\lambda}{1000} \\
I_{\text {sat }}=I_{\text {sat }, r}\left(\frac{T}{T_{r}}\right)^{3} \exp \left[\frac{q E_{G O}}{K A}\left(\frac{1}{T_{r}}-\frac{1}{T}\right)\right]
\end{gathered}
$$

The symbols in (5) to (7) have the following definitions and units:

- $\quad$ i - cell output current, Ampere.

- $\mathrm{I}_{\mathrm{g}}$ - light-generated current, Ampere.

- $\mathrm{I}_{\text {sat }}$ - saturation current, Ampere.

- $\mathrm{q}$-elementary charge, $q=1.60 \times 10^{-19}$ Coulomb.

- A - ideality factor, dimensionless.

- $\mathrm{K}$ - Boltzmann constant, $K=1.38 \times 10^{-23}$ Joule $/$ Kelvin

- $\mathrm{T}-$ cell absolute temperature, Kelvin.

- $\mathrm{R}_{\mathrm{s}}-$ series resistance, Ohm.

- $\mathrm{I}_{\mathrm{sc}}-$ short circuit current at the reference temperature, Ampere.

- $\mathrm{K}_{\mathrm{I}}$ - short circuit current temperature coefficient, Ampere/Kelvin.

- $\mathrm{T}_{\mathrm{r}}$ - reference absolute temperature, Kelvin.

- $\lambda$ - insolation level, Watt/square meters.

- $\mathrm{I}_{\mathrm{sat}, \mathrm{r}}-$ saturation current at the reference temperature, Ampere.

- $\mathrm{E}_{\mathrm{GO}}$ - band gap, electron Volt.

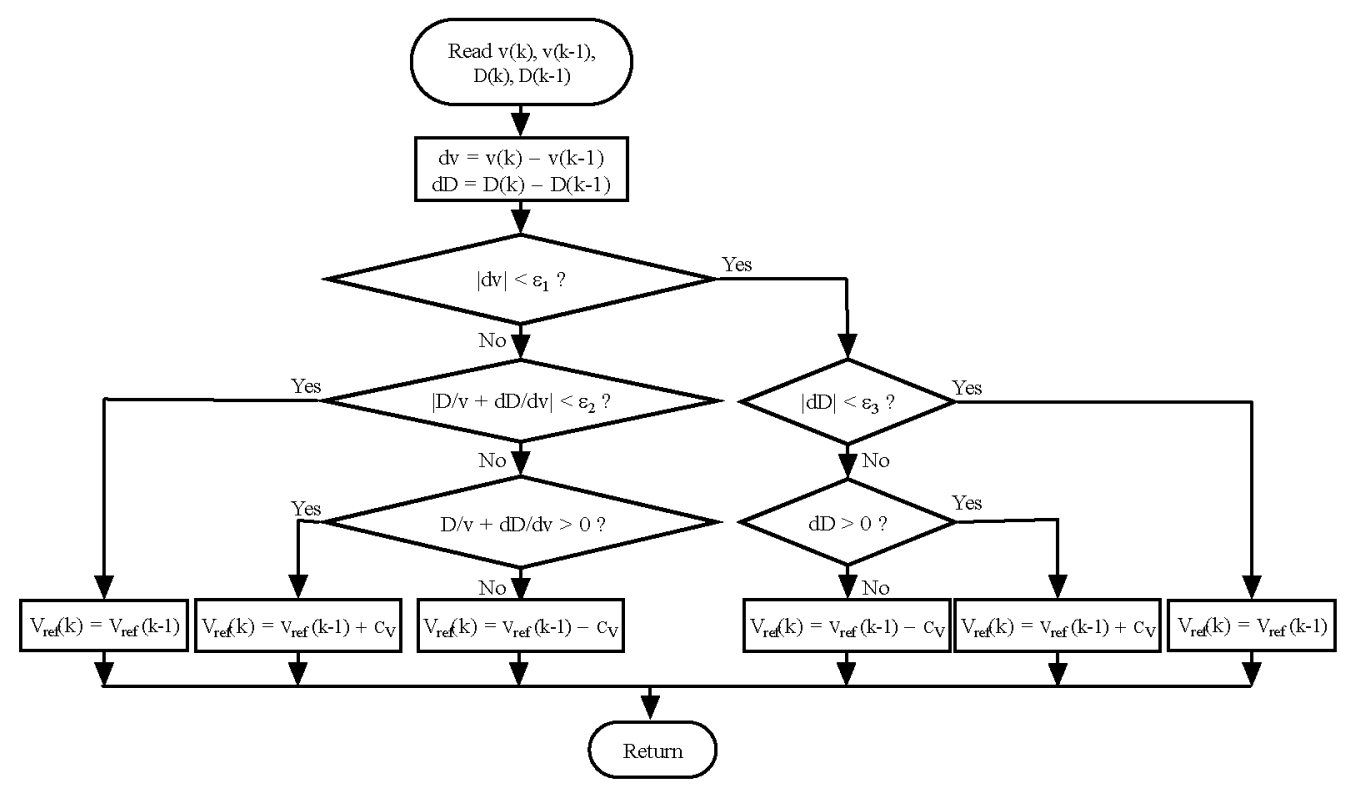

Fig. 5. Flowchart of the proposed MPPT algorithm 
For the $\mathrm{GaInP}_{2} / \mathrm{GaAs} / \mathrm{Ge}$ triple-junction cells, the saturation current at the reference temperature and the ideality factor can be found by the following equations [14]:

$$
\begin{aligned}
I_{s a t, r} & =\prod_{j} I_{s a t, r, j}^{A_{j} / A} \\
A & =\sum_{j} A_{j}
\end{aligned}
$$

where $\mathrm{A}_{\mathrm{j}}$ and $\mathrm{I}_{\mathrm{sat}, \mathrm{r}, \mathrm{j}}\left(j=G a I n P_{2}\right.$, GaAs and $\left.G e\right)$ are respectively the ideality factor and the saturation current at the reference temperature of each junction. Equation (7) can be written for the individual junctions as:

$$
I_{s a t, j}=I_{s a t, r, j}\left(\frac{T}{T_{r}}\right)^{3} \exp \left[\frac{q E_{G O, j}}{K A_{j}}\left(\frac{1}{T_{r}}-\frac{1}{T}\right)\right]
$$

where $\mathrm{E}_{\mathrm{GO}, \mathrm{j}}\left(j=G a I n P_{2}, G a A s\right.$ and $\left.G e\right)$ is the band gap of each junction.

According to (8) and (10), the total saturation current can then be written as:

$$
\begin{aligned}
I_{\text {sat }} & =\prod_{j} I_{\text {sat }, j}^{A_{j} / A} \\
& =I_{\text {sat }, r}\left(\frac{T}{T_{r}}\right)^{3} \exp \left[\frac{q}{K A} \sum_{j} E_{G O, j}\left(\frac{1}{T_{r}}-\frac{1}{T}\right)\right]
\end{aligned}
$$

Comparisons of (7) and (11) yield:

$$
E_{G O}=\sum_{j} E_{G O, j}
$$

The important parameters of the three junctions are listed in Table I [14], [15].

Other parameters such as $\mathrm{I}_{\mathrm{sc}}, \mathrm{K}_{\mathrm{I}}$ and $\mathrm{T}_{\mathrm{r}}$ can be found from the manufacture's datasheet [16]. Through (5) to (7), the solar cells current-voltage and power-voltage characteristics can be plot in Figs. 6 and 7, where solid lines represent the cell curves under the reference temperature $28^{\circ} \mathrm{C}$ and the dashed lines represent those under $60^{\circ} \mathrm{C}$. The cell curves under two different insolation levels, $600 \mathrm{~W} / \mathrm{m}^{2}$ and 1000 $\mathrm{W} / \mathrm{m}^{2}$ are drawn under each temperature.

TABLE I

JUNCTION PARAMETERS

\begin{tabular}{|c|c|c|c|}
\hline Junction & $\begin{array}{c}\text { Saturation Current } \\
\text { Density }\left(\mathrm{A} / \mathrm{cm}^{2}\right)\end{array}$ & $\begin{array}{c}\text { Ideality } \\
\text { Constant }\end{array}$ & $\begin{array}{c}\text { Band Gap } \\
(\mathrm{eV})\end{array}$ \\
\hline $\mathrm{GaInP} 2$ & $1 \times 10^{-14}$ & 2.1 & 1.85 \\
\hline $\mathrm{GaAs}$ & $1 \times 10^{-12}$ & 1.5 & 1.42 \\
\hline $\mathrm{Ge}$ & $1 \times 10^{-6}$ & 1.5 & 0.67 \\
\hline
\end{tabular}

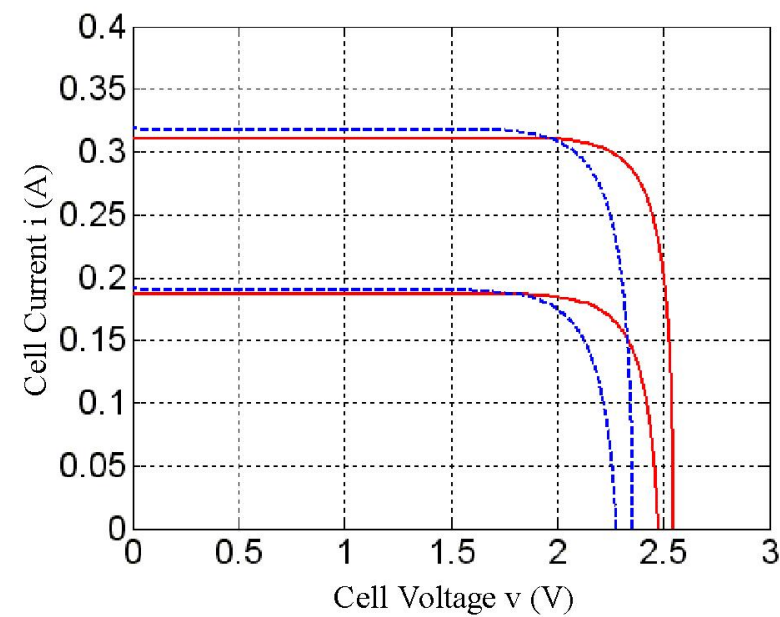

Fig. 6. Solar cell current-voltage curve

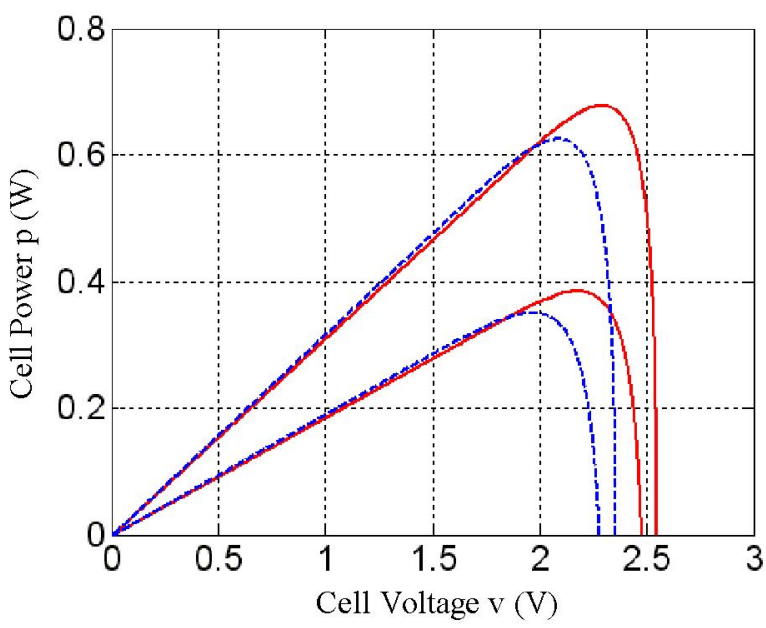

Fig. 7. Solar cell power-voltage curve

\section{Simulation Results}

The solar cell model in Section IV is used in the simulation circuit. The simulation is concentrated on the MPPT response to the insolation changes as these are far more rapid than the temperature changes in the vehicular applications. An inner PI control loop forces the cell voltage to track a reference voltage as the cell voltages at MPP vary only slightly under insolation changes. The outer control loop is MPPT control, which provides voltage set points to the faster running inner PI control loops. The MPPT loop runs once for every 16 inner PI loop executions.

Fig. 8 shows the simulated waveforms of the cell output voltage, current, power and the converter duty ratio between $0.3 \mathrm{~s}$ and $0.4 \mathrm{~s}$. At $0.32 \mathrm{~s}$, the insolation level changes from $600 \mathrm{~W} / \mathrm{m}^{2}$ to $1000 \mathrm{~W} / \mathrm{m}^{2}$. As the cell output current increases and charges the converter input capacitor to a higher voltage, the duty ratio is rapidly increased by the PI controller. At $0.36 \mathrm{~s}$, the insolation level changes from 1000 $\mathrm{W} / \mathrm{m}^{2}$ to $600 \mathrm{~W} / \mathrm{m}^{2}$ and the PI controller quickly decreases the duty ratio to maintain the previous reference voltage. 

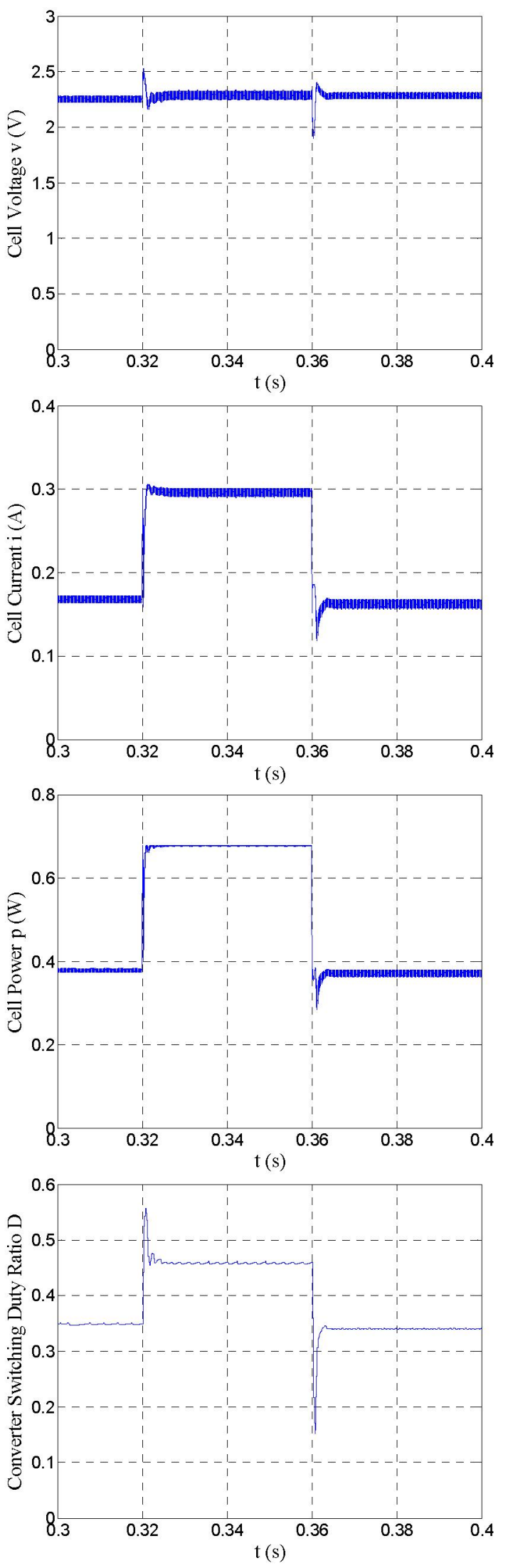

Fig. 8. Simulation waveforms
Fig. 9 shows the simulation waveforms of the cell power under the step-up and the step-down insolation changes. As shown in Fig. 9, the proposed IncCond method brings the cell to a new maximum power point in $1 \mathrm{~ms}$ when the insolation level steps up from $600 \mathrm{~W} / \mathrm{m}^{2}$ to $1000 \mathrm{~W} / \mathrm{m}^{2}$. At $0.36 \mathrm{~s}$, the insolation level steps down from $1000 \mathrm{~W} / \mathrm{m}^{2}$ to $600 \mathrm{~W} / \mathrm{m}^{2}$ and the new MPP is established in $2 \mathrm{~ms}$.

\section{EXPERIMENTAL RESUlts}

A solar cell simulator is made with silicon diodes and a switchable current source [4]. The current-voltage and power-voltage characteristics of the solar cell simulator are respectively shown in Figs. 10 and 11. These are obtained by allowing the simulator to charge a capacitor from zero voltage, an initially short circuit condition, and capturing the dynamic output voltage and current with a digital oscilloscope until the solar cell simulator finally settles at the open circuit condition. An important feature of this approach is that the real MPP condition of the solar cell simulator can be more directly and accurately observed.

A load consisting of a $2500-\mu \mathrm{H}$ inductor and a $4.1-\Omega$ resistor is applied to the buck converter. Figs 12 and 13 show the experimental waveforms under instantaneous insolation changes. It is worth mentioning that as shown in Fig. 3, the feedback voltage to the ADC in the
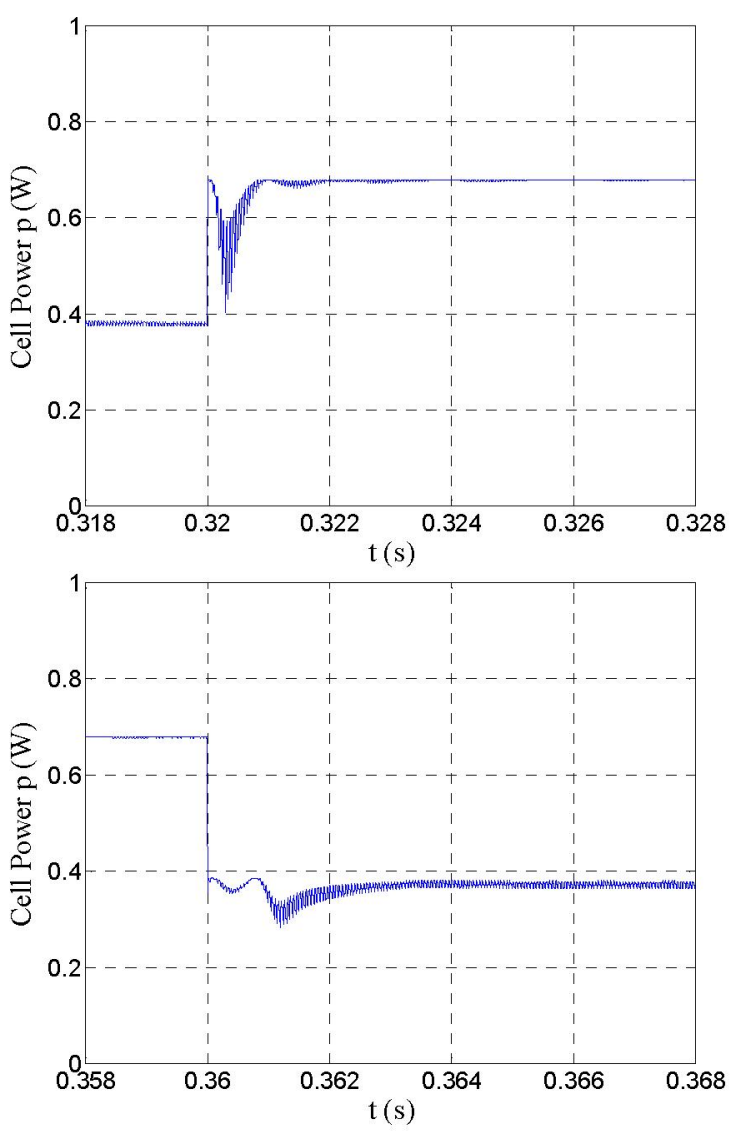

Fig. 9. Simulation waveforms 


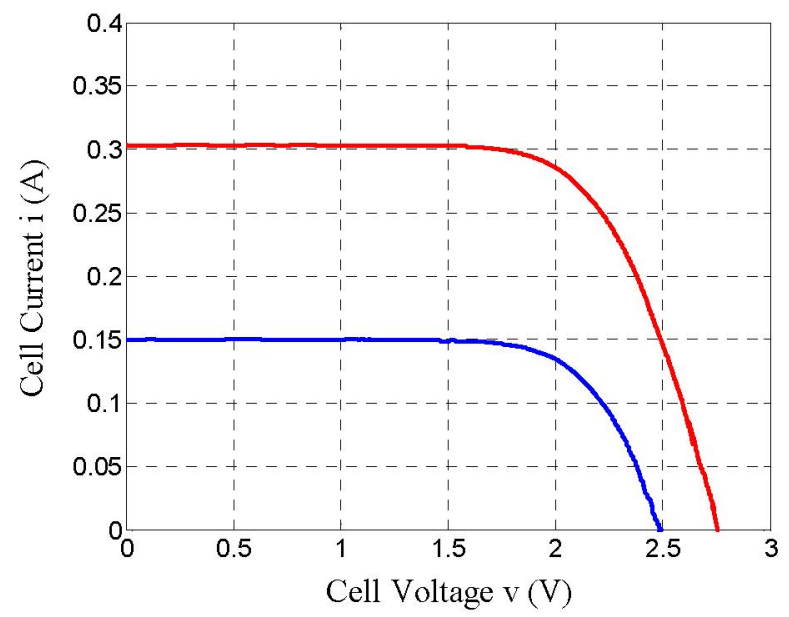

Fig. 10. As measured solar cell simulator current-voltage curve

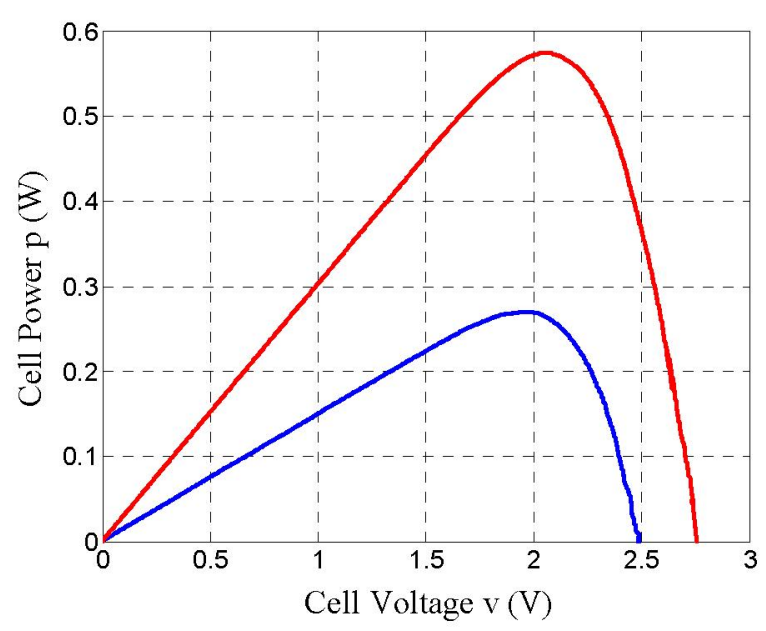

Fig. 11. As measured solar cell simulator power-voltage curve

microprocessor is obtained through a voltage divider made up of two resistors $R_{1}$ and $R_{2}$ and it corresponds to half of the solar cell simulator output voltage.

From top to bottom, Fig. 12 respectively shows the feedback voltage, the converter output mid-point to ground voltage, the cell output current and the converter output current when the insolation steps up instantaneously. Initially, the cell output current produces a step change and this charges the converter input capacitor voltage to a higher level. The cell voltage will move past the MPPT until the PI controller responds by increasing the converter switching duty ratio. The MPPT control loop runs at a lower rate than the PI control loop and provides the direction of the change in the reference voltage after a certain number of PI control loops. It can be observed that the establishment of the new MPP is largely complete within $1.5 \mathrm{~ms}$.

Fig. 13 shows the same set of the experimental waveforms when the insolation steps down instantaneously. The instantaneous drop in the cell current below the converter input current discharges the converter input capacitor to a lower level until the PI control loop responds by decreasing the converter switching duty ratio and brings the cell output voltage to the set point cell voltage. As the operating points fall in the constant current region of the cell current-voltage curve, the change in the cell output current is extremely small over the course. Again, the new MPP is established within $1.5 \mathrm{~ms}$.

The tracking performance under insolation changes can be further evaluated by the analysis of the cell output power shown in Figs. 14 and 15. The waveform data are recorded by the oscilloscope and exported to MATLAB. In Figs. 14 and 15 , the dashed lines represent the available maximum powers of the cell under the two insolation conditions and these are obtained from Fig. 11. The solid lines represent the

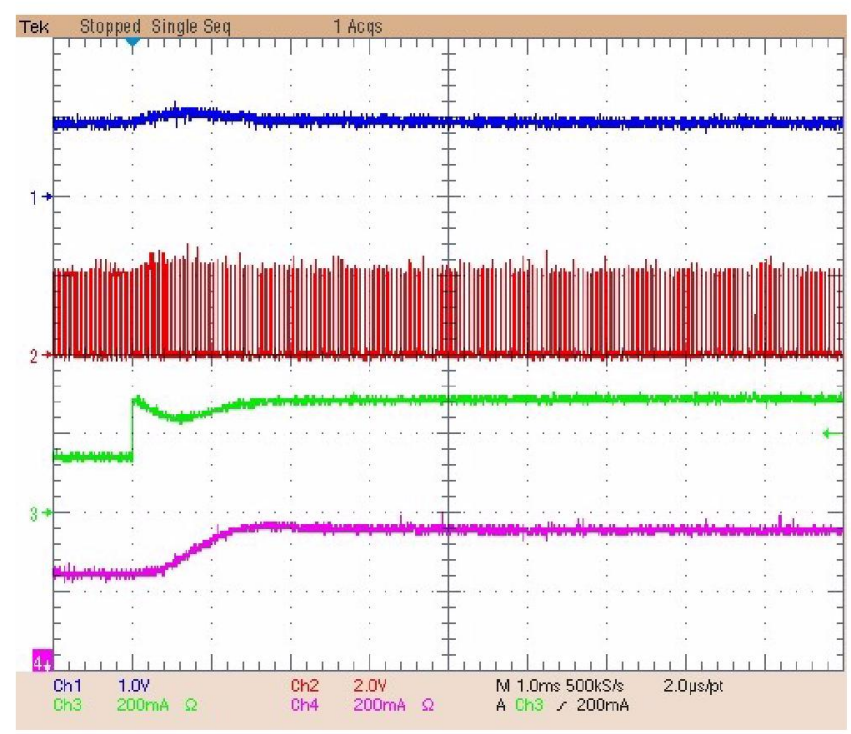

Fig. 12. Experimental waveforms - insolation step-up

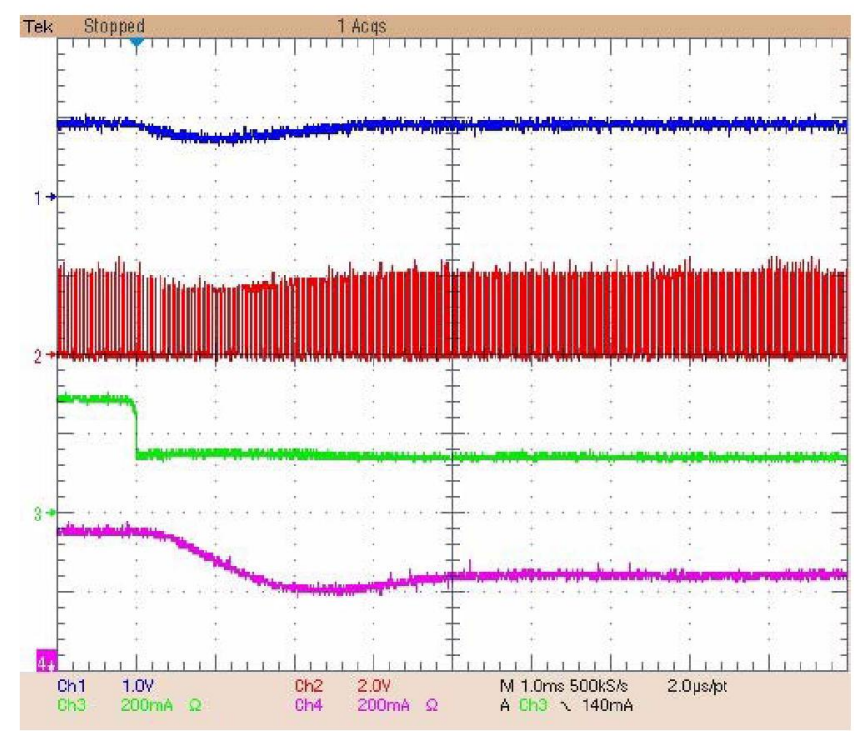

Fig. 13. Experimental waveforms - insolation step-down 
cell output curve captured by the mathematic function of the oscilloscope equipped with the voltage and current probes. The area between the two lines in each plot is the energy loss due to the insolation changes.

\section{CONCLuSIONS}

This paper proposes a new MPPT algorithm based on the conventional IncCond method, which is implemented on an MPPT device targeting at highly distributed MPPT arrangement for vehicle solar arrays. The proposed MPPT method is able to establish MPP purely on the cell output voltage and the converter switching duty ratio and therefore is current sensor free. This method can be readily applied to any load types where power increases monotonically with voltage. A triple junction solar cell model has also been explicitly established and this is a useful foundation in the simulation process. Finally, the simulation and experimental waveforms and a brief tracking performance analysis are provided to validate the theoretical analysis. The

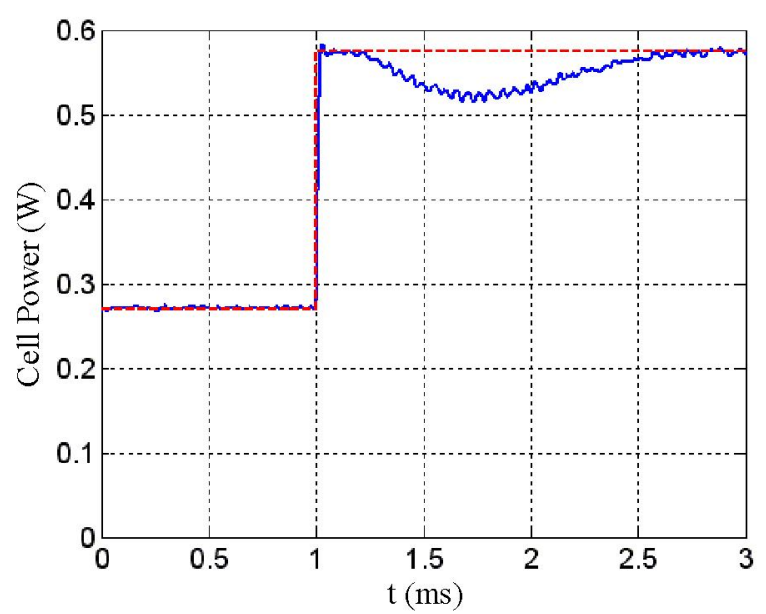

Fig. 14. Cell output power under step-up insolation

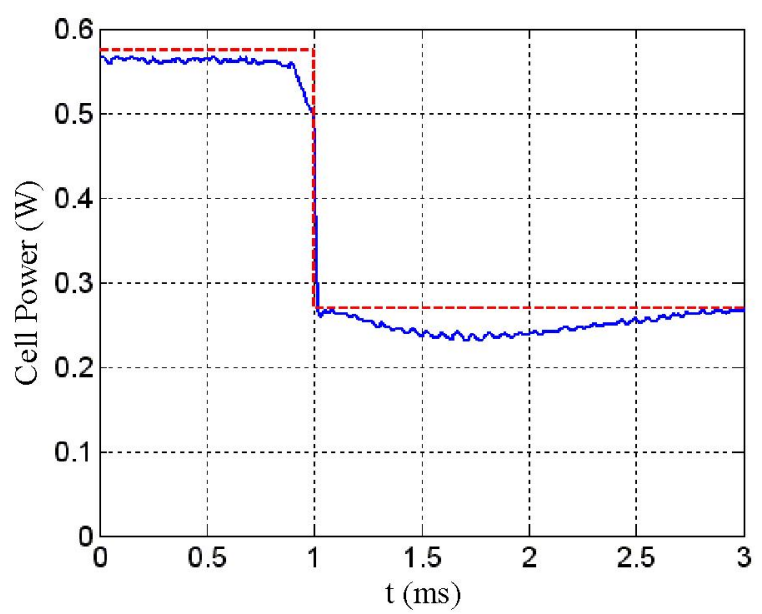

Fig. 15. Cell output power under step-down insolation experimental results confirm that a 1.5-ms response time can be secured for the proposed MPPT algorithm under rapid insolation changes.

\section{ACKNOLEDGEMENT}

This work was supported by the Queensland Department of Public Works and Housing and the Queensland Department of Transport.

\section{REFERENCES}

[1] J. Voelcker, "Top 10 tech cars, here come the hybrids," IEEE Spectrum, Mar. 2004, pp. 20-27.

[2] A. Simpson, G. Walker, M. Greaves, D. Finn and B. Guymer, "The ultra commuter: a viable and desirable solar powered commuter vehicle," in Proc. Australasian Universities Power Engineering Conference, 2002

[3] Emcore Corporation. InGaP/GaAs/Ge triple-junction solar cells [Online]. Available: http://www.emcore.com/assets/photovoltaics/ Triple.pdf

[4] P. Wolfs and L. Tang, "A single cell maximum power point tracking converter without a current sensor for high performance vehicle solar arrays," in Proc. IEEE PESC, 2005, pp. 165-171.

[5] D. Patterson, "Simple calorimetry for accurate loss measurement," IEEE Power Electronic Society Newsletter, pp. 5-7, Oct. 2000.

[6] H. Matsuo and F. Kurokawa, "New solar cell power supply system using a boost type bidirectional dc-dc converter," IEEE Trans. Ind. Electron., Vol. 31, No. 1, pp. 51-55, Feb. 1984.

[7] T. Noguchi, S. Togashi and R. Nakamoto, "Short-current pulse-based maximum-power-point tracking method for multiple photovoltaicand-converter module system," IEEE Trans. Ind. Electron., Vol. 49, No. 1, pp. 217-223, Feb. 2002.

[8] J. J. Schoeman and J. D. van Wyk, "A simplified maximal power controller for terrestrial photovoltaic panel arrays," in Proc. IEEE PESC, 1982, pp. 361-367.

[9] J. H. R. Enslin, M. S. Wolf, D. B. Snyman and W. Swiegers, "Integrated photovoltaic maximum power point tracking converter," IEEE Trans. Ind. Electron., Vol. 44, No. 6, pp. 769-773, Dec. 1997.

[10] D. Lee, H. Noh, D. Hyun and I. Choy, "An improved MPPT converter using current compensation method for small scaled PVapplications," in Proc. IEEE APEC, 2003, pp. 540-545.

[11] O. Wasynczuk, "Dynamic behavior of a class of photovoltaic power systems," IEEE Trans. Power App. Syst., Vol. 102, No. 9, pp. 30313037, Sept. 1983

[12] B. K. Bose, P. M. Szczesny, and R. L. Steigerwald, "Microcomputer control of a residential power conditioning system," IEEE Trans. Ind. Applicat., Vol. 21, No. 5, pp. 1182-1191, Sept./Oct. 1985.

[13] K. H. Hussein, I. Muta, T. Hoshino and M. Osakada, "Maximum photovoltaic power tracking: an algorithm for rapidly changing atmospheric conditions," in IEE Proc. Generation, Transmission and Distribution, Vol. 142, No. 1, pp. 59-64, Jan. 1995.

[14] K. C. Reinhardt, C. S. Mayberry, B. P. Lewis and T. L. Kreifels, "Multijunction solar cell iso-junction dark current study," in Proc. IEEE Photovoltaic Specialists Conference, 2000. pp.1118-1121.

[15] D. Friedman, J. Geisz, A. Kibbler, C. Kramer, S. Kurtz, B McMahon, J. Olson, A. Ptak and M. Young. (2002, April). $\mathrm{GaInP} / \mathrm{GaAs} / \mathrm{Ge}$ ultrahigh-efficiency solar cells. [Online]. Available: http://vmsstreamer1.fnal.gov/ VMS_Site_02/Lectures/colloquium/ Presentations/Friedman.pdf

[16] Spectrolab Inc. (2002, May). 25.1\% GaInP2/GaAs/Ge triple junction solar cells. [Online]. Available: http://www.spectrolab.com/ DataSheets/TJCell/ti.pdf 